\title{
KONSTRUKSI TES KEBAHASAAN UAS SD DI KABUPATEN MADIUN
}

\author{
Nur Samsiyah \\ Apri Kartikasari H.S \\ Chrisna Emilia \\ Prodi PGSD FIP IKIP PGRI MADIUN
}

\begin{abstract}
Language learning is aimed to achieve proficiency properly. To achieve objectives of language learning cannot be separated from aspects of grammar. One way to achieve the grammatical aspect is by using a test. The purpose of language test is ability and skill in language not knowledge about language. Range of aspects are measured based on the types of tests used in the test questions at the end of the learning/formative. This research aimed to determine language aspects tested at the end of each semester. This study used a qualitative approach and data sources in the form of the exam end of semester 1 and 2 grade 1 to grade 6. Techniques of data collection is done by collecting data source in the field and read the data source. Data analysis phase consists of three stages: data reduction, classification, presentation of data and drawing conclusions. The results showed there were aspects of language such as phonology, morphology aspect which consists of free and bound morpheme, the process of reduplication or repetition, syntactic aspects that form phrases and sentences as well as aspects such as semantic meaning.
\end{abstract}

Keywords: Final Exam, Linguistic aspects

\begin{abstract}
Abstrak
Pembelajaran bahasa bertujuan mencapai kemampuan berbahasa dengan baik dan benar. Untuk mencapai tujuan tersebut pembelajaran bahasa tidak dapat dilepaskan dari aspek tata bahasa. Salah satu cara mencapai aspek tata bahasa tersebut adalah tes. Tes bahasa dapat disebut dengan tes kebahasaan karena sasaran pokoknya adalah kemampuan berbahasa bukan pengetahuan tentang bahasa. Jangkauan aspek yang diukur berpegang kepada jenis tes yang digunakan pada soal tes pada akhir pembelajaran/tes formatif.Penelitian ini bertujuan untuk mengetahui aspek kebahasaan yang diujikan di setiap akhir semester. Penelitian ini menggunakan pendekatan kualitatif dengan sumber data berupa soal ujian akhir semester 1 dan 2 kelas 1 sampai dengan kelas 6. Teknik pengumpulan data dilakukan dengan mengumpulkan sumber data di lapangan dan membaca sumber data. Tahap analisis data terdiri dari tiga tahap yaitu reduksi data, klasifikasi, penyajian data dan penarikan simpulan. Hasil penelitian menunjukkan terdapat aspek kebahasaan berupa fonologi, aspek morfologi yang terdiri atas morfem bebas dan terikat, proses reduplikasi atau pengulangan, aspek sintaksis yang berupa frase dan kalimat serta aspek semantik yang berupa makna.
\end{abstract}

Kata Kunci: Ujian Akhir Semester, aspek Kebahasaan 


\section{A. Pendahuluan}

Pembelajaran keterampilan berbahasa pada dasarnya merupakan upaya meningkatkan keterampilan, menyimak, berbicara, membaca dan menulis. Dalam pelaksanaannya keempat keterampilan itu harus mendapatkan porsi pembelajaran yang seimbang dalam konteks yang alami, dan secara terpadu. Santoso (2008:1.7) menyatakan bahwa ada beberapa faktor yang mempengaruhi keberhasilan dalam belajar bahasa adalah kondisi eksternal dan internal. Alek dan Ahmad (2011:25) menyatakan bahwa bahasa Indonesia juga telah mampu mengemban fungsinya sebagai sarana komunikasi modern dalam penyelenggaraan pemerintahan, pendidikan, pengembangan ilmu teknologi serta seni. Dengan meningkatkan empat keterampilan dasar berbahasa, yaitu: mendengar berbicara, membaca dan menulis.

Pelaksanaan penilaian yang dilakukan dengan benar akan menjamin peningkatan kualitas pembelajaran. Pernyataan tersebut sesuai dengan Nurgiantoro (2011:5) yang menyatakan bahwa penilaian hasil pembelajaran merupakan bagian integral dari keseluruhan proses kegiatan belajar mengajar. Setelah peserta didik melalui berbagai proses pembelajaran, penyampaian informasi berupa materi pelajaran, biasanya dilaksanakan penilaian. Penilaian juga dilakukan setelah peserta didik melakukan praktik atau latihan. Penilaian ini berfungsi untuk mengetahui sejauh mana peserta didik dapat menyerap materi yang telah diajarkan. Penilaian ini biasanya dilakukan di akhir kegiatan pembelajaran dan mengukur kadar pencapaian tujuan atau disebut juga sebagai evaluasi.

Tes bahasa dapat disebut dengan tes kebahasaan karena sasaran pokoknya adalah kemampuan berbahasa bukan pengetahuan tentang bahasa. Jangkauan aspek yang diukur berpegang kepada jenis tes yang digunakan pada soal tes pada akhir pembelajaran/tes formatif. Sebagai perwujudan tes yang bersifat integral. Djiwandono (2011: 12) mengartikan tes bahasa sebagai alat ukur atau prosedur yang digunakan dalam melakukan penilaian dan evaluasi pada umumnya pada kemampuan bahasa dengan melakukan pengukuran terhadap tingkat kemampuan penguasaan bahasa. Tes bahasa tersebut dapat ditujukan untuk mengukur bahasa pada umumnya atau salah satu dari keempat jenis kemampuan bahasa: menyimak, menulis, membaca dan berbicara. Hal ini sesuai dengan pendapat Nurgiantoro (2010:277) yang menyatakan bahwa tes bahasa dalam kaitannya atau sebagai bagian pembelajaran bahasa, baik bahasa pertama, bahasa kedua, maupun bahasa asing. Lebih lanjut diungkapkan bahwa tes bahasa merupakan alat yang dipakai untuk mencoba mengukur seberapa banyak peserta didik telah menguasai bahasa yang dipelajari. 
Dalam pelaksanaan tes
bahasa, guru SD lebih mementingkan aspek menulis dari pada kemampuan yang lain, sehingga penilaian yang digunakan berasal dari ulangan siswanya. Ulangan umum dan ulangan harian merupakan salah satu kegiatan evaluasi yang yang memiliki nilai strategis karena berhubungan langsung dengan tujuan setiap program pembelajaran. Ulangan umum dilakukan pada setiap akhir semester atau biasa disebut dengan ulangan akhir semester 1 dan semester 2. Ulangan umum yang dilaksanakan pada akhir semester pada umumnya menyangkut keseluruhan aspek bahasa. Salah satu tes pada ulangan semester menekankan pada satu aspek kebahasaan pada satu waktu atau menggunakan tes diskret. Namun tidak jarang yang telah menggunakan tes integratif.

$$
\text { Penggunaan ulangan }
$$

semester juga telah dilakukan oleh Kabupaten Madiun. Ulangan umum semester atau yang biasa dinamakan UAS dilaksanakan pada setiap akhir pembelajaran semester. Alasan pemilihan soal ulangan semester sebagai subjek penelitian karena soal ini disusun oleh tim KKG Kabupaten Madiun dan dipakai oleh sebagian besar sekolah SD di Kabupaten Madiun. Soal ini merupakan soal terbaru, soal ujian tahun pertama yang digunakan untuk mengetahui keberhasilan pengajaran bahasa Indonesia berdasarkan kurikulum tingkat satuan pendidikan. penelitian ini dirumuskan masalah bagaimana aspek-aspek tata bahasa bahasa Indonesia yang diujikan dalam ujian akhir semester (UAS) bahasa Indonesia SD? Penelitian ini bertujuan untuk mendapatkan deskripsi objektif tentang tes tata bahasa Indonesia yang diujikan dalam ujian akhir semester bahasa Indonesia SD.

Tata bahasa yang digunakan dalam pengajaran bahasa adalah tata bahasa pedagogis. Tata bahasa pedagogis dapat disamakan dengan tata bahasa yang dirancang untuk pembelajaran bahasa. Tata bahasa pedagogis adalah model tata bahasa yang sudah terdeteksi dari satu etau lebih sumber tata bahasa ilmiah dan atas pertimbangan hasil studi sosiologi dan psikologi bahasa mengenai proses belajar mengajar bahasa Indonesia atau untuk membantu siswa menguasai keterampilan bahasa.

Menurut Kamus Besar Bahasa Indonesia edisi keempat, konstruksi adalah susunan dan hubungan kata dalam kalimat atau kelompok kata. Menurut Fatimah (1999:12) makna konstruksi (bhs. Inggris construction meaning) adalah makna yang terdapat dalam konstruksi, misalnya, makna milik yang diungkapkan dalam urutan kata di bahasa Indonesia. Di samping itu, makna milik dapat diungkapkan melalui enklitik sebagai akhiran yang menunjukkan kepunyaannya. Menurut Sarwiji (2008: 71) yang dimaksud dengan makna konstruksi (construction meaning) adalah 
makna yang terdapat dalam konstruksi kebahasaan. Jadi, makna konstruksi dapat diartikan sebagai makna yang berhubungan dengan kalimat atau kelompok kata yang ada didalam sebuah kata dalam kajian kebahasaan.

Materi yang tercakup dalam tata bahasa pedagogis mencakup materi tata bahasa ilmiah yang sudah disesuaikan dengan tujuan pengajaran. Ruang lingkup materi tata bahasa tersebut dimaksudkan untuk mengantarkan pembelajar agar dapat memiliki kompetensi berbahasa. Pembelajaran berbahasa bertujuan untuk mencapai kualitas komunikasi yang baik. Hal itu dapat dicapai apabila empat subkompetensi berbahasa dapat dikuasai yaitu kompetensi gramatikal, kompetensi sosiolinguistik, kompetensi kewacanaan, dan kompetensi strategik. Jadi ruang lingkup tata bahasa pedagogis mencakup kompetensi gramatikal, kompetensi sosiolinguistik, kompetensi kewacanaan, dan kompetensi strategik. Aspek tata bahasa pedagogik bahasa Indonesia adalah aspek fonologi, aspek morfologi, dan aspek sintaksis.

\section{Fonologi}

Secara etimologi kata fonologi berasal dari gabungan kata 'fon' yang berarti bunyi, dan logi yang berarti 'ilmu'. Sebagai sebuah ilmu fonologi lazim diartikan sebagai bagian dari kajian linguistik yang mempelajari, membahas, membicarakan, menganalisis bunyi-bunyi bahasa yang diproduksi oleh alat-alat ucap manusisa. Objek kajian fonologi adalah bunyi-bunyi bahasa yang dihasilkan oleh alat ucap atau alat bicara manusia. Menurut Chaer (2007:54) kajian fonologi terutama untuk mengetahui fonem-fonem dari suatu bahasa. Hal-hal yang berkaitan dengan fonem-fonem tersebut misalnya, alofon dari fonem-fonem itu, jenis-jenis fonem dari bahasa tersebut, proses terjadinya fonem, fonem serapan dari bahasa lain, pola silabel, pola deret vocal dan deret konsonan. George Yule (2006:43) menyatakan "phonology is essentially the description of the systems and patterns os speech sounds in a language".

Menurut status atau hierarki satuan bunyi terkecil yang menjadi objek kajiannya, fonologi dibagi atas dua bagian, yaitu fonetik dan fonemik. Fonetik adalah cabang yang mengkaji bunyi-bunyi bahasa tanpa memperhatikan statusnya, apakah bunyi-bunyi bahasa itu dapat membedakan makna (kata) atau tidak. Sedangkan fonemik adalah cabang kajian fonologi yang mengkaji bunyi-bunyi bahasa dengan memperhatikan fungsinya sebagai pembeda makna (kata). Kajian fonetik contohnya, tani-batik adalah tidak sama. bunyi u pada kata susu dan dapur juga tidak sama. sebaliknya bunyi $b$ dan $\mathrm{p}$ pada kata kabur dan kapur menyebabkan kedua kata itu memiliki makna yang tidak sama. ketidaksamaan ini adalah karena berbedanya bunyi $b$ dan $p$ itu meskipun bunyi-bunyi yang ada di sekitarnya 
memiliki ciri yang sama. inilah contoh dari objek kajian fonemik.

\section{Morfologi}

Secara etimologi morfologi berasal dari kata morf yang berarti bentuk dan kata logi yang berarti ilmu. Sehingga secara harfiah morfologi berarti 'ilmu mengenai bentuk'. Dalam kajian linguistic morfologi berarti ilmu mengenai bentu-bentuk dan pembentukan kata. Dalam ilmu biologi diartikan sebagai ilmu mengenai bentukbentuk sel-sel tumbuhan atau jasad-jasad hidup. Dalam kajian biologi digunakan istilah morfologi karena kedua-duanya sama-sama mempelajari tentang bentuk. Objek kajian morfologi adalah satuan-satuan morfologi, proses-proses morfologi dan alatalat dalam proses morfologi. Satuan morfologi adalah morfem (akar atau afiks) dan kata.

Sedangkan

Chaer

(2007:56) mengemukakan bahwa kajian morfologi terutama dilakukan untuk menemukan morfem-morfem dari suatu bahasa.

Berkenaan dengan morfem tersebut dapat dikaji untuk mengetahui alomorf dari morfem, jenis dan kategori morfem dari bahasa, proses pembentukan kata dari morfem-morfem tersebut, klasifikasi atau kategori kata dan system morfofonemik dari bahasa.

Morfem adalah satuan gramatikal terkecil yang bermakna. Chaer (2012:146) menyatakan bahwa sebagai satuan fungsional, morfem ini merupakan satuan gramatikal terkecil yang mempunyai makna. Morfem dapat berupa akar (dasar) dan dapat berupa afiks. Bedanya akar dapat menjadi dasar dalam pembentukan kata, sedangkan afiks tidak dapat. Akar memiliki makna leksikal, sedangkan afiks hanya 'menjadi' penyebab terjadinya makna gramatikal. Sedangkan kata adalah satuan gramatikal yang terjadi sebagai hasil dari proses morfologis.

Proses morfologis adalah proses atau peristiwa pembentukan kata. Menurut Kridalaksana (1992:12) proses morfologis terdiri atas 1) derivasi zero, 2) afiksasi, 3) reduplikasi, 4) abreviasi (pemendekan), 5) komposisi (perpaduan), 6) derivasi balik. Sedangkan menurut Chaer (2012:146) pembentukan kata mempunyai dua sifat yaitu inflektif dan derivative. Sedangkan proses morfologis atau proses gramatikal, khususnya pembentukan kata dengan afiks berkenaan dengan afiksasi, reduplikasi, komposisi, dan konversi dan modifikasi intern. Afiksasi adalah proses pembubuhan afiks pada sebuah dasar atau bentuk dasar. Menurut Kridalaksana (1992:28) afiksasi adalah proses yang mengubah leksem menjadi kata kompleks. Dalam proses ini leksem (1) berubah bentuknya, (2) menjadi kategori tertentu, sehingga berstatus kata, (3) sedikit banyak berubah maknanya.

Dalam bahasa Indonesia dikenal jenis-jenis afiks yang diklasifikasikan sebagai (Kridalaksana, 1992:28) prefiks, 
afiks yang diletakkan di muka dasar, konfiks, dan infiks.

Menurut Chaer (2008:16), jenis-jenis morfem dapat dibagi sebagai berikut.

1. Berdasarkan kebebasannya untuk dapat digunakan langsung dalam pertuturan dibedakan adanya morfem bebas dan morfem terikat. Morfem bebas adalah morfem yang tanpa keterkaitannya dengan morfem lain dapat langsung digunakan dalam pertuturan. Morfem terikat dapat pula berupa morfem dasar seperti, \{henti\}, \{juang\}, dan \{geletak\}. Morfem tersebut harus diberi afiks terlebih dahulu, misalnya \{juang\} menjadi berjuang.

2. Berdasarkan keutuhan bentuknya dibedakan menjadi morfem utuh dan morfem terbagi. Morfem utuh secara fisik merupakan satu kesatuan yang utuh. Yang termasuk morfem utuh adalah semua morfem dasar, baik bebas maupun terikat, serta prefix, infiks dan sufiks. Sedangkan yang dimaksud morfem terbagi adalah semua morfem yang fisiknya terbagi atau disisipi morfem lain. Karenanya semua konfiks (seperti pe-an, ke-an, dan per-an) adalah termasuk morfem terbagi.

3. Berdasarkan kemungkinan menjadi dasar dalam pembentukan kata, dibedakan morfem dasar dan orfem afiks. Morfem dasar adalah morfem yang dapat menjadi dasar dalam suatu proses morfologi.

4. Berdasarkan jenis fonem yang membentuknya dibedakan adanya morfem segmental dan morfem suprasegmental. Morfem segmental adalah morfem yang dibentuk oleh fonem-fonem segmental, yakni morfem yang berupa bunyi dan dapat disegmentasikan. Sedangkan morfem suprasegmental adalah morfem yang terbentuk dari nada, tekanan, durasi dan intonasi.

5. Berdasarkan kehadirannya secara konkrit dibedakan adanya morfem wujud dan morfem takberwujud. Morfem wujud adalah morfem yang secara nyata ada, tetapi yang tak berwujud kehadirannya tidak nyata. Morfem tak berwujud ada dalam bahasa Inggris.

6. Berdasarkan ciri semantiknya dibedakan adanya morfem bermakna leksikal dan morfem tak bermakna leksikal. Morfem leksikal di dalam dirinya secara inheren, telah memiliki makna. Sedangkan morfem afiks seperti, morfem \{ber-\}, \{ke-\}, dan $\{$ ter- $\}$ termasuk morfem tak bermakna leksikal.

\section{Sintaksis}

Sintaksis adalah bagian atau cabang dari ilmu bahasa yang membicarakan seluk beluk wacana. Sintaksis sebagai bagian dari ilmu bahasa berusaha menjelaskan unsur-unsur itu dalam suatu satuan baik hubungan fungsional maupun 
hubungan maknawi. Menurut Ida Bagus (2009:19) jenis kalimat berdasarkan isinya dapat dibedakan menjadi tiga bagian, yaitu kalimat berita, kalimat tanya dan kalimat perintah.Kalimat berita adalah kalimat yang mendukung suatu pengungkapan peristiwa atau kejadian.Kalimat berita diawali dengan huruf besar dan diakhiri dengan tanda titik. Soedjito dan Djoko Saryono (2012:87) menyatakan bahwa kalimat berita adalah kalimat yang isinya menyatakan berita. Lebih lanjut dikatakan bahwa kalimat berita dapat berupa jenis kalimat apa saja, misalnya kalimat verbal/nominal, kalimat aktif/pasif, kalimat lengkap/tidak lengkap, kalimat biasa/inversi atau kalimat tunggal/majemuk.

Kalimat tanya berfungsi
untuk menanyakan sesuatu.
Kridalaksana (1993) menyebutkan kalimat tanya dengan istilah kalimat interogatif, yaitu kalimat yang mengandung intonasi interogatif; dalam ragam tulis biasanya diberi tanda tanya

(?).Kalimat perintah adalah kalimat yang isinya menyuruh orang lain untuk melakukan sesuatu yang kita kehendaki (Ida Bagus, 2009:31). Kridalaksana (1993) menyebutkan kalimat perintah dengan istilah kalimat imperatif, yakni kalimat yang mengandung intonasi imperatif; dalam ragam tulis biasanya diberi tanda seru (!).
Dalam bahasa Indonesia, kita memiliki empat kategori sintaktis utama: 1) verba atau kata kerja, 2) nomina atau kata benda, 3) adjektiva atau kata sifat, dan 4) adverbia atau kata keterangan. Disamping itu ada kelompok yang disebut kata tugas. Kata tugas ini mencakup preposisi atau kata depan, konjungtor, dan partikel.

\section{Semantik}

Kata semantik dalam bahasa Indonesia (Inggris: semantics) berasal dari bahasa Yunani sema (kata benda" yang berarti "tanda" atau lambang. Kata kerjanya adalah semaino yang berarti "menandai" atau "melambangkan". Yang dimaksud dengan tanda atau lambang disini sebagai padanan kata sema itu adalah tanda linguistic (Perancis: signe linguistique")

Verhaar (1981:9) mengemukakan bahwa semantik (inggris: semantics) berarti teori makna atau teori arti, yakni cabang sistematik bahasa yang menyelidiki arti. Aminuddin menyatakan bahwa semantik mengandung pengertian studi tentang makna dengan anggapan bahwa makna menjadi bagian dari bahasa, maka semantik merupakan bagian dari linguistik.

Makna dapat pula diteliti melalui fungsi, dalam pemahaman fungsi hubungan antarunsur (struktur-hubungan antarstruktur-strukturalisme de Saussure). Dengan demikian kita mengenal makna leksikal (makna leksem itu sendiri) dan makna gramatikal (hubungan antarunsur secara fungsional); demikian pula ada makna kata, frase, klausa, kalimat, dan wacana sehingga 
ruang lingkup semantik dapat menjangkau semua tataran bahasa, fonologi, morfologi, sintaksis, dan wacana, bahkan teks.

Karena bahasa itu digunakan untuk berbagai kegiatan dan keperluan dalam kehidupan bermasyarakat, maka makna bahasa itu pun menjadi bermacammacam dilihat dari sudut pandang berbeda. Berbagai nama jenis makna telah dikemukakan oleh orang dalam berbagai buku linguistik maupun semantik.

Abdul Chaer (2009: 60) menyatakan bahwa makna leksikal dari suatu kata adalah gambaran yang nyata tentang suatu konsep seperti yang dilambangkan kata itu. Lebih lanjut Abdul Chaer (2009:62) mengungkapkan bahawa makna leksikal itu berkenaan dengan makna leksem atau kata yang sesuai dengan referennya. Makna gramatikal ada jika terjadi proses gramatikal seperti afikasi, reduplikasi, komposisi atau kalimatisasi. Makna gramatikal ini sering disebut juga makna kontekstual atau makna situasional. Selain itu juga disebut makna struktural karena proses dan satuan-satuan gramatikal itu selalu berkenaan dengan strktur ketatabahasaan. Abdul Chaer (2009:62) menyatakan bahawa makna gramatikal adalah makna yang hadir sebagai akibat adanya proses gramatika seperti proses afiksasi, proses reduplikasi dan proses komposisi. Selain itu ada masih ada berbagai makna diantaranya makna referensial dan nonreferensial, makna denotasi dan konotasi, makna konseptual dan makna asosiatif, makna peribahasa.

Tes diartikan sebagai alat penguji atau proses pengujian. Dalam dunia pendidikan, tes hasil belajar merupakan persoalan-persoalan atau aturan-aturan yang dirancang sedemikian rupa untuk mengukur perolehan belajar siswa. Fungsi tes ini adalah sebagai penguji kemampuan kognitif dan sebagai penguji perbuatan.

Berdasarkan wujudnya, tes dibedakan menjadi dua, yaitu tes tulis dan tes lisan. Tes tulis, sering dikenal dengan paper and pencil test, yaitu soalsoal yang diwujudkan dalam bentuk tulisan, demikian pula dengan jawabannya. Sedangkan tes lisan adalah alat untuk mengukur kemampuan siswa yang disampaikan secara lisan oleh penguji dan harus dijawab secara lisan pula oleh siswa.

Tes tulis sendiri memiliki beragam jenis, di antaranya: prates, pascates, tes sumatif, tes formatif, tes remidial, dan sebagainya.Tes formatif merupakan sekelompok pertanyaan yang digunakan untuk mencari informasi tentang kelemahan program pembelajaran melalui kemampuan yang telah dicapai siswa. Tes ini diujikan apabila suatu program pembelajaran atau bagian dari program tersebut selesai dilaksanakan. Oleh karena itu, lingkup atau luas bahan yang diujikan relatif sempit. 


\section{B. Metode Penelitian}

Penelitian ini bertujuan untuk mengkaji konstruksi tes kebahasaan dalam evaluasi pembelajaran bahasa Indonesia SD khususnya ujian akhir semester (UAS). Peneliti berperan sebagai instrumen utama. Penelitian ini menggunakan pendekatan kualitatif. Berdasarkan rancangan penelitian, maka jenis penelitian ini adalah penelitian kualitatif yang bersifat eksploratif. Penelitian kualitatif adalah penelitian yang prosedur penelitiannya menghasilkan data deskriptif berupa kata-kata tertulis atau lisan yang dapat diamati. Sumber data penelitian berupa dokumen yaitu soal-soal ujian akhir semester 1 dan 2 yang digunakan untuk evaluasi pembelajaran bahasa Indonesia SD. Alasan pemilihan soal UAS karena se-kabupaten Madiun menggunakan soal yang sama yang dibuat dalam kelompok kerja guru atau KKG. Penelitian ini termasuk penelitian populatif. Subjek/populasi penelitian ini berupa paparan verbal materi tata bahasa yang diujikan dalam evaluasi pembelajaran Bahasa Indonesia SD.

\footnotetext{
Pengumpulan data pada tahap persiapan adalah memantapkan penguasaan konseptual berkaitan dengan tata bahasa, evaluasi, dan hal-hal yang berhubungan dengan teknik penelitian. Menurut Sugiono
}

(2007:224) teknik pengumpulan data merupakan langkah yang paling strategis dalam penelitian, karena tujuan utama dari penelitian adalah untuk mendapatkan data. Pada tahap pengumpulan data dilakukan kegiatan membaca sumber data, dan mengumpulkan data. Dalam penelitian ini, peneliti menggunakan triangulasi dengan sumber data yaitu dengan membandingkan dan mengecek baik derajat kepercayaan suatu informasi yang diperoleh melalui waktu dan cara yang berbeda.

Analisis data dalam penelitian kualitatif dilakukan sebelum memasuki lapangan, selama dan setelah di lapangan. Dalam penelitian ini peneliti melakukan analisis data pada saat setelah di lapangan. Aktivitas dalam analisis data kualitatif dilakukan secara interaktif dan berlangsung terusmenerus, sehingga datanya jenuh. Aktivitas dalam analisis data, yaitu, data reduction (reduksi data), penyajian data, penarikan kesimpulan dan verifikasi.

Tahap analisis data terdiri dari tiga tahap yaitu reduksi data yang berupa kegiatan identifikasi aspek fonologi, morfologi, dan sintaksis, dan klasifikasi. Kemudian dilanjutkan dengan kegiatan penyajian data dan penarikan simpulan. Data yang sudah ada diidentifikasi dan diklasifikasi berdasarkan jenisnya secara sistematis dalam bagian paparan dan pembahasan hasil penelitian. Untuk menganalisis data dilakukan secara kualitatif dengan berpedoman pada deskriptor yang disajikan pada tabel analisis sebagai berikut. 


\section{Hasil Penelitian dan \\ Pembahasan \\ a. Hasil Penelitian}

Data yang diambil dalam penelitian ini berupa ujian akhir semester yang dilaksanakan pada akhir semester 1 dan semester 2 wilayah kabupaten Madiun. Karena data yang digunakan dalam satu wilayah tersebut sama maka diambil sampel dua sekolah dasar sebagai data penelitian. Data yang diperoleh terdiri dari ujian akhir semester mulai kelas 1 sampai dengan kelas 6 sekolah dasar. Jumlah soal untuk kelas 1 dan kelas 2 sebanyak 40 soal yang terdiri dari 25 soal pilihan ganda, 10 soal uraian singkat dan 5 soal uraian panjang. Sedangkan jumlah soal untuk kelas 3 sampai dengan kelas 6 terdiri dari 35 soal pilihan ganda, 10 soal dengan jawaban singkat dan 5 soal uraian panjang. Masingmasing kelompok soal diberi romawi I, II, dan III. Beberapa aspek fonologi yang dijumpai di sekolah dasar pada Ujian Akhir Semester di kelas 1 sampai kelas VI semester 1. Fonologi yang diujikan dalam UAS terdiri dari fonem-fonem atau kelas bunyi. Data-data fonem yang diketahui dan dicatat adalah sebagai berikut. [baju] [tahun] [lebah] [kəlas] [haru] Fon/f.1-5 [baru] [tanda] [lemah] [kaki] [rabu] Fon/f.6-10

[biru] [terima] [leher] [halaman] [pagi] Fon/ f.11-15 [baik] [salam] [rapi] [təmpat] [lain]

Fon/f.16-20

[becak] [putih] [rajin] [topi]

Fon/f.21-24

[bəsar] [sepeda] [paman] [jantan]

Fon/f.25-28

[bibi] [lompat] [sabun] [sapi]

Fon/f.29-32

[bulu] [tali] [dipan] [waktu]

Fon/f.33-36

[bulat] [tangan] [mata] [lagu]

Fon/f.37-40

[bu奋] [kambing] [tubuh] [pola]

Fon/f.41-44

[bola] [kurus] [lemari] [bərsih] Fon/f.45-48

Ada beberapa bunyi fonetis yang mirip misalnya [baju], [rabu], [haru], [tahun], [sabun], [topi], [rapi], [tangan], [paman], [halaman] sehingga dapat dituliskan huruf fonetisnya yaitu, [b]- $[\mathrm{r}]$ $[\mathrm{h}],[\mathrm{t}]-[\mathrm{s}],[\mathrm{t}]-[\mathrm{r}],[\mathrm{t}]-[\mathrm{p}]-[\mathrm{h}]$. Sedangkan bunyi-bunyi selebihnya, [s] [w][1] [b] [k] [l] [j]. Selain itu ada beberapa bunyi yang memiliki pasangan minimal diantaranya.

[pola] [bola]

[rapi] [sapi]

[lebah] [lemah]

[tahun] [sabun]

[baru] [haru]

Ada beberapa alofon yang terdapat di dalam soal. Fon/a.1.o terdiri dari kata montor, monolog, toko, polisi, emosi, kota, obat, telepon, bola dan domestik. Kata yang termasuk dalam Fon/a.1.O dalam pengucapannya berbeda dengan o atau dengan kata lain sama tulisannya berbeda lafalnya, misalnya rokok, pokok, tokoh, tolong. Kata hitam 
akan sama dengan pergi, polisi, janji, kursi karena sama dalam membacanya. Kata tersebut termasuk dalam alofon i (Fon/a.2.i). Sedangkan Fon/a.2.I terdapat dalam kata misalnya tulis, air, baik, baris berbeda pengucapannya meskipun pemakaiannya samasama menggunakan huruf i. Begitu pula dengan pemakaian huruf e yang dalam penulisannya sama namun berbeda lafalnya. Huruf e yang yang masuk dalam Fon/a.3.e misalnya cerdik, pergi, kecil, koperasi, benih, sedangkan yang dibaca ə seekor dan emosi. Ada bunyi e yang dibaca ẻ misalnya dalam kata domestik.

Morfem yang ada dalam soal bahasa Indonesia kelas 1 sampai dengan kelas 6 semester 1 dan 2 sekolah dasar didaftar sebagai berikut:

1) Morfem berdasarkan kemampuan berdistribusi diantaranya kata siapa, wah

2) Morfem bebas (Mor/b.1) yang terdiri dari hadiah, teman, peringkat, tanda, maaf, salam, baik, sekolah, mata, suara, makan, lemah, kurus, sehat, besar, upacara, salin.

3) Sedangkan morfem terikat (Mor/t.2) terdiri dari dua morfem atau lebih yaitu terdapat pada soal; berendra, membuat, mengucapkan, digunakan, memakai, meraba, mendengarkan, mencari, membangunkan, membaca, menyimpan, membuang, menyebabkan, melanggar, mengakibatkan, membantu, menghangatkan, menghidupkan, mendapat, melengkapi, menghubungkan, melengkapi, menanyakan, menjalankan, mendapatkan, menghadapi, menceritakan, memanggil, mengharap, membuat, menulis, menuliskan, melaporkan, memerankan, membaca, menanggapi, membersihkan, menerapkan, melakukan, mengikuti, memperingati, menggambarkan, memajukan, menghemat, mengapa, membicarakan, terganggu, lemparkan, berdasarkan, meniupkan, melaksanakan, menonton, memiliki, menulis, membutuhkan, menanam, memuaskan, menggabungkan, menguasi, meninggalkan, melihat, berjalan, bermain, berwarna, bertengkar, berkelahi, bernama, tuliskan, sebangku, bertepuk, bermain, berjudul, bersepeda, terjadinya, bersahutan, bergambar, bernama, bersama, dilahirkan, beberapa, bermanfaat, berguguran, bersemangat, terjatuh, berlatih, sebuah, anjuran, kritikan, tanggapan, berbelanja, pengganggu, terganggu, perumahan, bergaris, terlambat, terjebak, menguasai, penanaman, pemberian.

Afiks-afiks yang digunakan dalam soal ujian akhir semester dapat dilihat dari seperti berikut.

1) Prefiks ber- terdapat dalam kata: berendra, bermain, berwarna, bergizi, bergaris, bersama, bersahutan. 
Sedangkan makna gramatikalanya menyatakan mempunyai atau ada dan memakai atau menggunakan, menghasilkan.

2) Verba berkonfiks dan berklofiks terdapat dalam kata berguguran.

3) Klofiks ber-kan terdapat dalam kata berdasarkan, bersahutan

4) Sufiks kan- terdapat dalam kata lemparkan, tuliskan yang memiliki makna gramatikal lakukan akan.

5) Sufiks -i tidak ada dalam soal

6) Prefiks per-digunakan dalam kata perumahan dan pengganggu

7) Prefiks me- terdapat dalam bentuk atau alomorf yang berbentuk me-,(Mor/al.1) mem-, men-, meny-, meng-, dan menge-.

Sedangkan alomorf mem(Mor/al.2) digunakan pada kata membuat, membangunkan, membimbing, membaca, membeli, membersihkan, membawa, membuang, memberi. Alomorf men- (Mor/al/3) terdapat dalam kata mendengarkan, mencuci, menjemur, mencari, menjual, mencuci, menebang. Bentuk atau alomorf meng- (Mor/al.4) terdapat dalam kata mengapa, mengucapkan, mengalami mengakibatkan, menghidupkan, menghangatkan, menggembirakan, menghadap, mengharap, menghemat. Dan yang terakhir bentuk meny- (Mor/al.5) ada pada kata menyeterika, menyiapkan, menyempat kan, menyimpan, menyebabkan, dan menyapu.

Selain morfem bebas dan terikat di atas, terdapat proses reduplikasi (Mor/r.1 dan Mor/r.u.1) dalam soal yang diujikan dalam ujian akhir semester mulai kelas 1 sampai dengan kelas 6 semester 1 dan semester 2

Aspek sintaksis yang menjadi unsur kalimat, adalah frase dan klausa. Frase adalah kelompok kata yang mendukung suatu fungsi (subyek, predikat, pelengkap, obyek dan keterangan) dan kesatuan makna dalam kalimat. Beberapa frase atau kelompok kata yang dapat ditemukan dalam data soal kelas 1 adalah 'Paman mencangkul', bunga melati, baju biru, aku suka, sembarang tempat. Soal yang digunakan di kelas 1 dimulai dengan adanya wacana sederhana yang berjudul 'Gemar Membaca'. Dari wacana tersebut di bawahnya ada beberapa kalimat pertanyaan yang jawabannya ada pada bacaan. Kalimat tanya masuk dalam kategori Sin/k.t yang digunakan dalam soal. Beberapa soal pilihan ganda di kelas 6 ada beberapa soal yang menjadi perbedaan di kelas lain yaitu adanya wacana. Wacana yang terdapat dalam soal berfungsi untuk menjawab pertanyaan dengan mencari ide pokok, atau kalimat utama. Sedangkan penggunaan unsur-unsur kalimat dalam kelas 6 sudah memenuhi unsur minimal yang wajib ada. Penggunaan kalimat tunggal hanya terdapat pada kalimat Dayang Sumbi rajin beribadah, Ina 
gemar mengoleksi perangko, Dia baru saja pulang dari Jakarta.

Selain beberapa kalimat tunggal ditemukan data beberapa kalimat majemuk yang dibentuk dengan cara menggabungkan beberapa kalimat tunggal, misalnya (Sin/m.1)jangan lupa membaca doa terlebih dahulu sebelum pelajaran dimulai,(Sin/m.2) di larang mencoret-coret tembok karena mengotori lingkungan, (Sin/m.3) adik sakit panas dan ibu menyuruhku membeli obat,(Sin/m.4) noni tidak masuk sekolah sebab sakit malaria, meskipun bangun siang, Andi tidak akan terlambat ke sekolah.

Semantik merupakan ilmu yang mempelajari tentang makna. Dalam soal yang diujikan di sekolah dasar, semantik masih terbatas pada kelas 4 sampai dengan kelas 6. Hal ini disebabkan karena makna membutuhkan penalaran dalam mengartikan makna tersebut. Beberapa makna yang dipakai dalam kalimat yang termasuk dalam kategori Sem/m.1 yang terdapat dalam soal ujian diantaranya sebagai berikut.

1. Kakinya kokoh di batas cakrawala

2. Semua penduduk turun tangan membersihkan saluran air

3. Ayahku pulang dari desa membawa buah tangan

4. Ayo..., jangan berpangku tangan saja

5. Seperti telur di ujung tanduk
6. Aminah menjadi buah hati orang tuanya

7. Ayah menerima tamu itu dengan tangan terbuka

Kalimat di atas merupakan kalimat yang menggunakan makna tidak sebenarnya atau makna peribahasa. Kata di batas cakrawala, maksudnya adalah berdiri di tanah, arti kata turun tangan adalah bekerja. Begitu pula arti makna kata buah tangan yaitu jajan atau oleholeh yang dibawa oleh ayah.

\section{b. Pembahasan}

Data yang diperoleh dari hasil penelitian ujian akhir semester yang telah diujikan di sekolah dasar terdiri atas aspek fonologi, morfologi, sintaksis dan semantik. Aspek fonologi lebih banyak digunakan pada kelas 1 dan kelas 2 sekolah dasar yang terdiri atas huruf, fonem dan alofon. Data fonem terdapat pada Fon/f.1-48 yang telah diuraikan berdasarkan satuan terkecil. Hal ini sependapat dengan Samsuri (1983:129) yang menyatakan bahwa analisis fonemfonem sebuah bahasa akan berhasil dengan baik, apabila bahan yang dikumpulkan secara fonetis itu lengkap dan sangat berkecil-kecil. Selain data fonem terdapat alofon yang masih digunakan dalam kalimat sama di kelas 1 dan kelas 2. Alofon yang digunakan dalam kalimat diantaranya alofon dari o, i dan e. Alofon o terdapat dalam data Fon/a.1.o dan Fon/a.1.O, alofon i terdapat dalam data Fon/a.2 dan Fon/a.2.I serta alofon dari e yang terdapat dalam data Fon/a.3.e dan Fon/a.3.E. Selain data fonem dan alofon ditemukan data tentang 
penggunaan diftong diantaranya pada kata pantai, ramai, silau dan bersendau gurau.

Data morfologi yang diperoleh dari soal ujian akhir sekolah dasar terdiri dari morfem bebas dan morfem terikat. Morfem bebas terdapat dalam data Mor/b.1 Data yang diperoleh adalah Mor/b.2 misalnya mencuci yang berasal dari morfem bebas cuci dan morfem afiks me-. Hal ini senada dengan pendapat Abdul Chaer (2008:17) yang menyatakan bahwa morfem terikat adalah morfem yang harus terlebih dahulu bergabung dengan morfem lain untuk dapat digunakan dalam pertuturan.

$$
\text { Alomorf men- terdapat }
$$

dalam data Mor/al.1 diantaranya kata mendengarkan, mencuci, menjemur, mencari, menjual, mencuci, menebang. Bentuk atau alomorf meng- (Mor/al.2) terdapat dalam kata mengapa, mengucapkan, mengalami mengakibatkan, menghidupkan, menghangatkan, menghgembirakan, menghadap, mengharap, menghemat. Dan yang terakhir bentuk meny- (Mor/al.3) ada pada kata menyeterika, menyiapkan, menyempatkan, menyimpan, menyebabkan, dan menyapu.

Selain morfem bebas dan terikat di atas, terdapat proses reduplikasi (Mor/r.) dalam soal yang diujikan dalam ujian akhir semester mulai kelas 1 sampai dengan kelas 6 semester 1 dan semester 2 dapat di data sebagai berikut. Mor/r.19), dan Mor/r.u.1-8. Data tersebut menunjukkan adanya proses reduplikasi atau pengulangan. Reduplikasi yang dihasilkan termasuk ke dalam reduplikasi morfologis yang berupa akar atau dasar. Kata rumah-rumah, marahmarah adalah bentuk pengulangan utuh. Menurut Abdul Chaer (2008:181) pengulangan utuh artinya bentuk dasar itu diulang tanpa melakukan perubahan bentuk fisik dari akar itu, sehingga bentuk akar rumah-rumah adalah rumah.

Data penggunaan aspek sintaksis yang diujikan dalam ujian akhir semester berupa frase dan klausa serta kalimat yang terdiri atas kalimat tunggal, kalimat perintah, kalimat tanya dan kalimat pernyataan. Kalimat tunggal lebih banyak digunakan di kelas rendah yang polanya hanya SPO dan SPOK. Sedangkan di kelas tinggi telah menggunakan pola kalimat yang dikembangkan menjadi kalimat majemuk.

Aspek kebahasaan semantik yang terdapat dalam soal lebih banyak digunakan di kelas tinggi berupa makna dan arti dari makna tersebut. Makna yang digunakan lebih cenderung pada peribahasa terutama di kelas 5 dan kelas 6. Makna yang terdapat dalam kalimat "kakinya kokoh di batas cakrawala" merupakan kata yang tidak sesuai dengan makna referennya. Menurut Chaer (2009:61) makna leksikal dari suatu kata adalah gambaran yang nyata tentang suatu konsep seperti yang dilambangkan kata itu. Sedangkan yang dimaksud kaki 
pada kalimat di atas bukan kaki sebenarnya. Hal ini senada dengan pendapat Abdul Chaer (2009) tersebut yang menyatakan bahwa kata yang tidak sesuai dengan referennya bukan makna leksikal.

\section{Kesimpulan}

Dengan memperhatikan hasil penelitian yang telah dipaparkan dalam Bab IV, penelitian Konstruksi Tes Kebahasaan UAS Sekolah Dasar di Kab. Madiun dapat disimpulkan sebagai berikut: (I) aspek tata bahasa yang diujikan mencakup (1) aspek fonologi terdiri atas (a) huruf dan fonem, dan (b) alofon; (2) aspek morfologi terdiri atas (a) afiksasi, yang berupa kata berimbuhan, makna gramatikal dalam afiksasi, afiks serapan, penulisan kata berimbuhan, morfofonemik; (b) reduplikasi yang berupa proses reduplikasi, macam reduplikasi, dan makna proses reduplikasi, (3) aspek sintaksis terdiri atas (a) aspek kalimat yang terdiri atas frase dan klausa, struktur kalimat, kategori, fungsi, dan peran-peran unsur kalimat, serta jenis kalimat yang berupa kalimat pernyataan, kalimat perintah, kalimat pertanyaan, kalimat aktif, kalimat majemuk.

\section{Daftar Pustaka}

Burhan Bungin, M.2007. Penelitian Kualitatif, Komunikasi, Ekonomi, Kebijakan Publik dan Ilmu Sosial Lainnya. Jakarta: Kencana Prenada Media Group

Chaer, Abdul. 2007. Kajian bahasa. Jakarta: Rineka cipta

Chaer, Abdul. 2009. Pengantar Semantik Bahasa Indonesia. Jakarta: Rineka Cipta

Chaer, Abdul. 2012. Linguistic Umum. Jakarta: Rineka cipta

Depdiknas. 2006. Permendiknas No. 22 tahun 2006 tentang Standar Isi untuk Satuan Pendidikan Dasar dan Menengah.

Djiwandono. 2011. Tes Bahasa Pegangan Pengajar Bahasa. Jakarta: Indeks

Finoza, Lamuddin. 2002.. Komposisi Bahasa Indonesia. Jakarta: Insan Mulia.

George Yule. 2006. The Study of Language. University Press. Cambridge.

Gorys Keraf.1991. Tatabahasa Indonesia. Sekolah Menengah Tingkat Atas. NTT: Nusa Indah. 
